\title{
Q. 4:34 AND DISCIPLINING A WIFE: MODERN INDONESIAN MUSLIM SCHOLARS' INTERPRETATIONS OF THE QUR'AN
}

\author{
Yusuf Rahman \\ Syarif Hidayatullah State Islamic University (UIN) Jakarta \\ yusuf.rahman@uinjkt.ac.id
}

\begin{abstract}
Q. 4:34 is regarded by some scholars as one of the most controversial verses in the Qur'an. This verse can be divided into two parts: the first part deals with the qiwamah "guardianship" of males and the second part with the beating (darb) of the disobedient wives (nashiz). This last part is usually considered as the main cause of domestic violence or intimate partner violence in Muslim societies. (Ibrahim \& Abdalla, 2010)

Ayesha Chaudhry (Chaudhry, 2013) has comprehensively compared the classical and medieval interpretations of Q. 4:34, which, according to her, were influenced by the patriarchal and hierarchical worldview, with the modern responses. The latter then is divided into four responses: the traditionalists, the neo-traditionalists, the progressives, and the reformists.

This paper focuses on the interpretations of Indonesian Muslim scholars to see whether they are supporting the hierarchical worldview or the egalitarian one; belonging to the traditionalist and neo-traditionalist interpretations or the progressive and the reformist responses.
\end{abstract}

Keywords: Qiwamah, domestic violence, wife beating, wa 'dribuhunna, patriarchal and hierarchical worldview, egalitarian worldview

\section{Introduction}

Mohamed Mahmoud argues that there are many "problematic" verses in the Qur'ān. Several factors may cause these problems: some verses contradict other verses, some verses are not really clear what they mean, or other verses are problematic either to be taken textually or metaphorically (Mahmoud, 2006). Qur'ān 4:34 is regarded as one of these problematic verses. Karen Bauer even considers this verse as one of the most controversial verses in the Qur'ān today (Bauer, 2015).

Q. 4:34 reads:

Ar-rijālu qawwāmūna 'alā 'n-nisā'i bi-mā faḍdala 'llāhu ba 'dahum 'alā ba 'ḍin

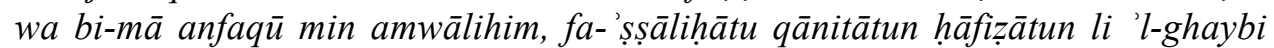
bi-mā hafiza 'llāhu, wa 'llātī takhāfüna nushūzahunna fa-'izūhunna wa 'hjurūhunna fì'l -maḍāji i $i$ wa' dribūhunna, fa-'in ața'nakum fa-lā tabghū 'alayhinna sabīlan, inna 'llāha kāna 'aliyyan kabīran

The translation of the verse as follows:

Men are qawwämūn over women according to what God faddala ba'dahum 'ala $b a$ ' $d$ (has favored some over some others) and bima anfaqu (according to what they spend) from their wealth. Righteous women are qānitāt (obedient) guarding the unseen according to what God has guarded. Those [women] whose nushüz (rebellion) you fear, admonish them, and abandon them in bed, and idribūhunna (strike them). If they obey you, do not pursue a strategy against them.

For other scholars, however, they would like to state that it is not the verse itself which is problematic but its androcentric interpretation. They would insist that "no verse 
of the Qur'ān can really have an oppressive androcentric intent; such an intent comes only from the male dominated interpretive tradition." (Scott, 2009, p. 60)

The first issue which is problematic in the interpretation of Q. 4:34 is the issue of qiwāmah, which is usually understood as male's superiority over women. Bauer, who has studied the classical and medieval interpreters of Q. 4:34, concludes that on the whole these scholars understand the Q. 4:34 as the basis for men's authority over women. Even though she sees the development of exegetical articulation on the verse, she argues that this development is the result of their use and appropriation of the Islamic turāth, especially the Qur'ān and the Prophetic traditions, for their age (Bauer, 2006).

Omaima Abou-Bakr, on the other hand, finds that the evolution of patriarchal interpretation of qiwāmah in Islamic tradition, from al-Tabarī to the modernist mufassir, consists of four discursive states (Abou-Bakr, 2015). The first stage which starts with alTabari was the transformation of the descriptive notion of qiwāmah into the prescriptive and normative conception of qiyam. This means that starting with Tabarī, qiwämah was understood as men's task of ahl al-qiyam, that is to watch over the women. The second stage was identified with al-Zamakhsharī, al-Rāzi and other mufassirs in their period who list some reasons and justifications for the divinely ordained superiority of men. In the third stage, the explanation of men's superiority expands from the domestic to the public sphere. Ibn Kathīr, for example, by using the hadīth lan yufliha qawmun wallathum imra'atun, argues against women's leadership. He and other mufassirs of ma'thür method, also strengthen their justification of men's superiority with many hadith. Finally, in the modern period, the mufassirs add the justification of men's superiority with the ideology of domesticity and scientific explanation of biological difference between men and women.

In addition to the problematic issue of male's role as qawwāmūn, Q. 4:34 also speaks of men's right to beat (idribü) their disobedient wives (nāshiza). This issue is controversial these days because it is considered as the main cause of domestic violence or intimate partner violence in Muslim societies. (Ibrahim \& Abdalla, 2010)

Some scholars have shown that this verse which seems to legitimate men's beating contradicts the Prophetic Sunnah and traditions. The Prophet, for example, says "Do not strike God's female servants," or "The best of you do not strike." In order to solve "this contradiction", classical Muslim scholars offer some strategy. Shāfi 'î, for example, proposes to "determin[e] which texts are meant to have general application and which are meant to apply narrowly, which commands (and prohibitions) are obligatory and which are merely recommendations, and whether and when one supplants another in a process known as abrogation or naskh" (Ali, 2006, p. 144). Shāfi '⿳亠丷厂, however, does not accept the concept of abrogation between the Qur'ān and the Sunnah, since both of them have equal standing and do not contradict each other. Shāfi ' 1 accepts the abrogation of the same type: the Qur'ān with the Qur'ān and Sunnah with Sunnah. In this case, he finds that through his chronological analysis of the Prophetic Sunnahs, the later Sunnah which tolerates striking abrogates the earlier Sunnah which forbids the striking of women (Ali, 2006, pp. 146, 148; See also Marín, 2003, p. 20).

In addition to this strategy, Mohamed Mahmoud demonstrates that scholars usually provide other strategies in reading Q. 4:34 to solve the problem., i.e., limitation strategy and virtual abrogation strategy (Mahmoud, 2006, p. 544ff.). The first strategy limits the beating with the qualification of "light" or "not grievous" (ghair mubarrih) beating. This strategy, however, still tolerates the beating. The last strategy, on the other hand, rejects the beating by virtually abrogating the verse insisting that the best of Muslims do not strike their wives. 
Another recent study on Q. 4:34 is Ayesha Chaudhry's Domestic Violence and Islamic Tradition (Chaudhry, 2013). In this work, Chaudhry argues that the classical and medieval interpretations of the Qur'àn are fully influenced by the patriarchal and hierarchical worldview. This kind of patriarchal approach, Chaudhry insists, can also be found in the modern readings of the Qur'ān: the traditionalist and neo-traditionalist interpretation. Contrary to these interpretations which propose patriarchal and hierarchical understanding, the progressive and the reformist approaches strive for egalitarian reading of the Qur' ān.

Based on these literature review, this paper analyzes modern Indonesian Muslim scholars' interpretation of Q. 4:34 to see whether they are supporting the hierarchical worldview or the egalitarian one; and belonging to the traditionalist and neo-traditionalist interpretations or the progressive and the reformist responses.

\section{Methods}

Following Johanna Pink's classification of tafsīr literature (Pink, 2010), the primary sources of this paper are Tafsir Al Azhar authored by HAMKA which represents popular tafsìr, Al-Qur'an dan Tafsirnya of Departemen Agama as the institutional tafsir , and Tafsir Al-Mishbāh of M. Quraish Shihab as the scholarly tafsìr.

These sources will be analyzed using the four groupings of Chaudhry. This categorization is based on their approaches to Islamic tradition. The traditionalist approach accepts the patriarchal and hierarchical worldview of the Islamic tradition and defends the right of husbands to discipline their wives; the neo-traditionalist approach supports the right of husbands to beat their wives but with some limitation and restrictions. The other two approaches reject the patriarchal and hierarchical worldview and hold the egalitarian worldview. The difference between the progressive and the reformist approaches, As Chaudhry explains, is that while the former prefers the egalitarian worldview by asserting "the minority or imagined opinions" of the Islamic tradition which support the egalitarian view to "retain authority in mainstream religious community," the latter, on the other hand, is willing to reject any tradition to maintain the egalitarian worldview.

\section{Discussion and Result}

On the issue of qiwāmah, our sources are fully in agreement that Q. 4:34 legitimates male's superiority over women. Shihab proposes the argument for this superiority to the textual declarations in the verse, those are: that God has favored some over some others and that husbands have spent their wealth for their wives and children (Shihab, 2000, p. 402). Before discussing male's inherent quality, Shihab proposes that the term ar-Rija $l$ in the verse has to be translated as men not husbands. This translation follows Muhammad Țāhir Ibn 'Āshūr who pronounces that the term ar-Rijāl is not used in Arabic language and also in the Qur'ān to mean husband. The term is different from the terms al-nis $\bar{a}^{\prime}$ and imra' $a h$ which have the clear meaning as wife.

In order to support men's inherent superior quality over women, Shihab refers to the modern research findings, like Anton Nemilove's The Biological Tragedy of Women, Murtaḍa Muțțahharî’s Niz̄ām Huqūq al-Mar'ah and some other psychological researches to justify the physical as well as the psychological superiority. Shihab further concludes that "function creates form" (fungsi menciptakan bentuk). (Shihab, 2000, p. 405) This means that for men to function perfectly as leader, God has created them in their best forms physically and psychologically.

In addition to this inherent quality, the superiority of men over women is stated in the verse bimā anfaqu, because of their spending from their wealth. According to Shihab, 
this factor is the most logical reason for men's superiority. He reasons that men's duty to spend their wealth for their families deserves the right to be leader.

Shihab's interpretation of this verse is similar to Ministry of Religious Affairs' interpretation. Actually, the latter's interpretation is shorter and simpler. It just interprets the term qawwām which is translated as "penanggung jawab" (person in charge), "pelindung" (protector), "pengurus" (manager), and also "pemimpin" (leader) (Departemen Agama Republik Indonesia, 1995, p. 154. See also Departemen Agama RI, 2004, p. 153)

What is interesting is the interpretation of HAMKA. He argues that men's leadership is a factual reality. The fact that men become the leader does not only happen in human beings, but also in animals. (HAMKA, 1983, p. 46) He further demonstrates that this status comes from men's instinct.

Having discussed the first part of Q. 4:34 on men's superiority over women, the second part deals with the husbands' right to discipline their wives physically. Tafsir Departemen Agama refers to a tradition narrated by Ḥasan al-Bașrī from Muqātil which states:

Jā'at imra'atun ilā l-Nabì șallā llāhu 'alayi wa sallama tashkū anna zawjahā laṭamahā. Fa-qāla rasūlu llāhi șallā llāhu 'alayhi wa sallama al-qișāṣ.

(A wife came to the Prophet, peace be upon him, reporting the her husband has slapped her. The Prophet then said retaliation, qișass, i.e., she should retaliate)

However, when she returned to her house, her husband could not get the retaliation from his wife because of this verse which permits the husband to hit his wife who does not obey her husband. (Departemen Agama RI, 2004, p. 169)

HAMKA also believes that as the leader in the family, a husband is allowed to hit his wife if needed. He does not agree with the statement that the hitting of the disobedient wife is not permitted.(HAMKA, 1983, p. 53) Even though HAMKA permits the hitting, he uses the strategy of limiting the hitting. He, for example, refers to the tradition which instructs the hitting by using the handkerchief and not the stick.

Similarly, Shihab understands wa' dribūhunna as hitting the wife. This disciplining of a wife is not aimed at hurting the wife. He refers to the tradition which prohibits hitting the face. At the end of his discussion of this verse, Shihab quotes Ibn 'Āshür interpretation of this verse, which warns the educated people that the striking of the wife is not the appropriate method.

Based on this discussion, we can see that all of our sources argue for the permission of the husband to strike his disobedient wife, based on their interpretation of this verse. Even though they limit the hitting, or using limitation strategy, they still permit the husband to strike.

\section{Conclusion}

The understandings of HAMKA, Departemen Agama and Shihab on Q. 4:34, to use Chaudhry's classification, belong to the traditionalist and neo-traditionalist approach to the Islamic tradition. Their insistent on men's superiority over women which is based on the inherent quality of men and women is influenced by the patriarchal and hierarchical worldview of the Islamic traditions which they refer to. They do not question critically these Islamic traditions.

In addition, their interpretation of Q. 4:34 which tolerates the right of husband to strike his wife is based on the textual understanding of the verse and the Prophetic Sunna. They do not refer to role of the Prophet who does not ever strike his wives, or to his Prophetic tradition: "The Best of You Do Not Strike." 


\section{References}

Abou-Bakr, O. (2015). The Interpretive Legacy of Qiwamah as an Exegetical Construct. In Z. Mir-Hosseini, M. Al-Sharmani, \& J. Rumminger (Eds.), Men in Charge? Rethinking Authority in Muslim Legal Tradition (pp. 44-64). London: Oneworld Publications.

Ali, K. (2006). "The Best of You Will Not Strike": Al-Shafi'i on Qur'an, Sunnah, and Wife-Beating. Comparative Islamic Studies, 2(2), 143-155.

Bauer, K. (2006). “Traditional” Exegesis of Q. 4:34. Comparative Islamic Studies, 2(2), $129-142$.

Bauer, K. (2015). Domestic Violence and the Islamic Tradition: Ethics, Law, and the Muslim Discourse on Gender. By Ayesha Chaudhry. Oxford: Oxford University Press, December 2013. Pp. xx258. HB 34.99. ISBN 78-0-19-964016-4. Journal of Qur'anic Studies, 17(2), 132-136. https://doi.org/10.3366/jqs.2015.0200

Chaudhry, A. (2013). Domestic Violence and the Islamic Tradition: Ethics, Law, and the Muslim Discourse on Gender. Oxford: Oxford University Press.

Departemen Agama Republik Indonesia. (1995). Al Qur'ān dan Tafsirnya Tahun 1995 (Vol. 2). Yogyakarta: Dana Bhakti Wakaf Universitas Islam Indonesia.

Departemen Agama RI. (2004). Al-Qur'an dan Tafsirnya Tahun 2004 (Vol. 2). Jakarta: Departemen Agama RI.

HAMKA, H. (1983). Tafsir Al Azhar (Vol. V). Jakarta: Pustaka Panjimas.

Ibrahim, N., \& Abdalla, M. (2010). A Critical Examination of Qur'an 4:34 and Its Relevance to Intimate Partner Violence in Muslim Families. Journal of Muslim Mental Health, 5(3), 327-349. https://doi.org/10.1080/15564908.2010.551278

Mahmoud, M. (2006). To Beat or Not to Beat: On the Exegetical Dilemmas Over Qur'an , 4:34. Journal of the American Oriental Society, 126(1992), 537-551.

Marín, M. (2003). Disciplining wives: A historical reading of qur'ân 4: 34. Studia Islamica, (97), 5-40.

Pink, J. (2010). Tradition and Ideology in Contemporary Sunnite Qur'ānic Exegesis: Qur'annic Commentaries from the Arab World, Turkey and Indonesia and their Interpretation of Q 5:51. Die Welt Des Islams, 50(1), 3-59. https://doi.org/10.1163/157006010X489801

Scott, R. M. (2009). A Contextual Approach to Women's Rights in the Qur'ān: Readings of 4:34. The Muslim World, 99(1), 60-86.

Shihab, M. Q. (2000). Tafsir al-Mishbāh: Pesan, Kesan dan Keserasian Al-Qur'an (Vol. 2). Ciputat: Lentera Hati. 